\title{
Breastfeeding and breast cancer: a case-control study in Southern Brazil
}

\author{
Amamentação e câncer de mama: \\ estudo de caso-controle no Sul do Brasil
}

Sérgi o Tessaro 1

Jorge U. Béria 2,3

Elaine Tomasi 2

Cesar G. Victora 2

\footnotetext{
1 Departamento Materno Infantil, Faculdade de Medicina, Universidade Federal de Pelotas. Rua Gonçalves Chaves 3027 , Pelotas, RS 96015-560, Brazil. tessaro.sul@terra.com.br 2 Programa de Pós-Graduação em Epidemiologia, Faculdade de Medicina, Universidade Federal de Pelotas. Av. Duque de Caxias 250, Pelotas, RS

96030-002, Brazil.

3 Programa de Pós-Graduação em Saúde Coletiva, Universidade Luterana do Brasil.

Rua Miguel Tostes 101, Canoas, RS

924420-280, Brasil.
}

Abstract To investigate the relationship between breastfeeding and breast cancer in Southern Brazil, a case-control design was employed, with two age-matched control groups. A total of 250 cases of breast cancer were identified in women from 20 to 60 years of age, with 1,020 hospital and community controls. The main study variables were occurrence of breastfeeding and durati on of breastfeeding. A multivariate conditional logistic regression analysi s was employed. According to the results, breastfeeding did not have a protective effect against breast cancer. The odds ratio (OR) for women who breastfed was 0.9 (95\% $\mathrm{Cl}: 0.8-1.2)$ compared to women who did not breastfeed. For women who breastfed for six months or less, the OR was 1.0 (95\% Cl: 0.6-1.8). In pre-menopausal women who breastfed for more than 25 months, the OR was $0.95(95 \% \mathrm{Cl}$ : 0.5-3.5), and in post-menopausal women OR was 1.27 (95\% Cl: $0.5-3.1)$, compared to women who had not breastfeed.

Key words Breast Neoplasms; Breastfeeding; Case-Control Studies

Resumo Para investigar esta relação, entre amamentação e câncer de mama no Sul do Brasil, utilizou-se um del ineamento de caso-controle com dois grupos de controles, emparel hados por idade. Foram identificados 250 casos de câncer de mama em mul heres de 20 a 60 anos e 1.020 controles hospitalares e controles de vizinhança. As principais variáveis estudadas foram a ocorrência e o tempo da amamentação. A análise multivariada foi realizada por mei o de regressão logística condicional, não encontrando efeito protetor da amamentação contra o câncer de mama. A razão de odds (RO) para quem amamentou foi de 0,9 (IC95\%: 0,8-1,2) comparando-se com quem não amamentou. Para as mul heres que amamentaram por seis meses ou menos, a RO foi de 1,0 (IC95\%: 0,6-1,8). Entre as mulheres na pré-menopausa que amamentaram por mais de 25 meses, a RO foi de 0,95 (IC95\%: 0,5-3,5) e na pós-menopausa foi de 1,27 (IC95\%: 0,5-3,1) comparando-se com o grupo das que não amamentaram.

Palavras-chave Neoplasias Mamárias; Aleitamento Materno; Estudos de Casos e Controles 


\section{Introduction}

The observation that early motherhood promotes a reduction in breast cancer risk indicates that reproductive and hormonal factors play an important role in the prevention of this neoplasm. Hormonal factors have the greatest effect on the mammary glands during puberty, pregnancy, and lactation, influencing cellular alterations (Russo \& Russo, 1995).

Numerous studies have focused on the relationship between reproductive factors and breast cancer risk. The main factors studied have been age at first delivery, parity, age at menarche, and age at menopause age (Harris et al., 1992).

Although much is known about risk factors for breast cancer (Harris et al., 1992), this knowledge has not resulted in successful preventive measures. Prevention is difficult because many factors are endogenous, thus making intervention more difficult (Hulka \& Stark, 1995).

Breast cancer accounts for $24 \%$ of all malignant neoplasms and 49,000 deaths per year among women in the United States (La Vecchia et al., 1990). Worldwide, more than one million new cases were estimated for the year 2000 (Miller \& Bulbrook, 1986). Breast cancer is the most common neoplasm in women from 45 to 65 years of age, with fewer than $5 \%$ of cases occurring among women under 30 years (Boring et al., 1994). The incidence curve has two peaks, at 50 and 70 years of age. In Brazil this disease accounts for $15 \%$ of female deaths (Chagas, 1994), and in Rio Grande do Sul State it is the leading cause of female cancer deaths (Rebelo, 1994).

It has been hypothesized that changes occurring during lactation protect women from breast cancer. These protective effects result from the release of cells transformed by milk production, which inhibit both cell growth and the appearance of pre-malignant clones, as well as the occurrence of secretory exchanges and cell proliferation (Fentiman, 1993).

In the city of Pelotas, Rio Grande do Sul, Brazil, prevalence rates for breastfeeding at six months postpartum in 1982 and 1993 were approximately 30 and 38\% (Horta et al., 1996; Barros et al., 1986).

Although various studies have demonstrated a protective effect of prolonged breastfeeding against breast cancer, mainly in premenopause (Byers et al., 1985; Collaborative Group on Hormonal Factors in Breast Cancer, 2002; Marcus et al., 1999; McTiernan \& Thomas, 1986; Newcomb et al., 1994; Olaya-Contreras et al., 1999; Tryggvadottir, 2001), many authors have not found the same effect (Brinton et al., 1995; Freudenheim et al., 1994; London et al., 1990; Michels et al., 1996, 2001; Thomas \& Noonan, 1993; UK National Case-Control Study Group, 1993). In Asian countries the effect appears to be more protective, but in the United States the effect is not as clear (Kelsey et al., 1993). In Amerindians in the State of Mato Grosso do Sul, Brazil, mean duration of breastfeeding was 84 months, and this appears to exert an important protective effect against breast cancer (Lima et al., 2001). In a review of the epidemiological literature, this relationship was not evidenced in either pre-menopausal or post-menopausal women (Lipworth et al., 2000).

The present study was designed to study the relationship between breastfeeding and breast cancer in women from the southern region of Rio Grande do Sul, Brazil.

\section{Methodology}

A case-control study was performed, using two control groups (hospital- and communitybased), which were analyzed jointly to increase the study power.

The reason for using two types of controls was to reduce bias. Hospital controls may not be representative of the population from which cases were recruited, particularly if severity of disease is not comparable (Schlesselman, 1982); on the other hand, community controls may be biased if access to health care is problematic (Schlessel man, 1982). Similar results from the control groups thus strengthen the study's findings. Most case-control studies employ only one type of control. Case-control is the design of choice for slowly evolving diseases, allowing the study of several risk factors for any given outcome.

\section{Sample}

Sample size was calculated with a $95 \%$ confidence level (two-tailed test) and $80 \%$ statistical power to detect a relative risk of 0.6 , assuming a breastfeeding prevalence rate at six months of $38 \%$ (Horta et al., 1996). The number of necessary cases (including allowance for losses, refusals, and adjustment for confounding) was 233. The control-to-case ratio was 4:1.

A total of 250 cases from 20 to 60 years of age were interviewed, all living in the southern region of Rio Grande do Sul, Brazil. Some 516 hospital controls and 504 community controls were recruited. 
The study included cases from Pelotas with both hospital and community controls and cases from other nearby cities with hospital controls from the same cities. Community controls were only obtained for cases from Pelotas due to the logistic difficulty of finding community controls in rural areas and other cities.

Losses and refusals were distributed as follows: among cases, two refusals and six losses (2.0\%); among controls, 32 refusals (3.2\%), of whom four were hospital-based and 28 community-based (2.4\%).

All 132 women over 60 years of age when breast cancer was diagnosed were excluded during data collection. This decision was due to potential recall bias, mainly in relation to duration of breastfeeding.

\section{Definition of exposure}

Interviewees provided data on the occurrence and duration of breastfeeding (in months) for each of their children, which were totaled to provide lifetime duration of breastfeeding. Table 1 lists the study variables and their respective scales.

\section{Case selection}

All incident breast cancer cases (diagnosed in the previous six months) in women 20 to 60 years of age recruited from March 1995 to July 1998 in hospitals, radiation therapy and chemotherapy services, and pathology labo- ratories in the cities of Pelotas and Rio Grande were included.

\section{Selection of controls}

For community controls, interviewers located the case's home and proceeded leftwards from door to door until three corresponding controls were found.

Hospital controls were obtained through random selection of hospital wards; when the number of hospitalized women exceeded three on the same day, the room number and if necessary the bed were also randomly selected. All controls were age-matched with cases (plus or minus five years).

Diagnoses leading to hospitalization of controls were as follows: acute clinical diseases (19.2\%), surgical conditions (12.8\%), trauma (9.9\%), pneumonia (9.9\%), bronchial asthma (9.7\%), sinusitis $(9.1 \%)$, peptic ulcer $(8.7 \%)$, pyelonephritis (8.5\%), gastroenteritis (8.5\%), and non-gynecological cancers (3.7\%).

\section{Data collection}

Cases and controls answered a pre-coded standardized questionnaire including sociodemographic, reproductive, breastfeedinghistory, and breast disease-history variables. The questionnaire also included information on various potential confounding variables (Table 1).

Table 1

Variables and scales employed in the case-control study of breast cancer.

\begin{tabular}{lll}
\hline Categories & Variables & Scales \\
\hline Socio-economical & Schooling (years completed) & Discrete \\
Demographic & Age (in years) & Continuous \\
& Skin color (white/non white) & Dichotomous \\
& Marital status (married/single) & Dichotomous \\
Family history & Breast cancer & Dichotomous \\
Personal history & Biopsy for benign breast disease & Dichotomous \\
Reproductive & Age at menarche & Dichotomous \\
& Age of first child & Continuous \\
& Number of children & Discrete \\
& Number of abortions & Continuous \\
Breastfeeding & Oral contraceptives & Dichotomous \\
& Menopause & Continuous \\
& Occurrence (yes/no) & Dichotomous \\
& Duration (in months) & Continuous
\end{tabular}


$\underline{\text { Logistics }}$

The team consisted of five interviewers and five supervisors, one in each recruiting site, to identify cases and controls and record their ages and addresses. All controls were interviewed within three months of case identification.

Data analysis

The collected data were initially cleaned through an analysis of the range and distribution of study variables and their mutual consistency. Distribution of study factors was then calculated for cases and controls, as well as the respective odds ratios, $95 \%$ confidence intervals, and significance tests. Statistical software SPSS Incorporation 6.0 for Windows and Epi Info were employed for both approaches.

Data were then submitted to multivariate analyses, employing conditional logistic regression (according to the procedure described by Breslow \& Day, 1980), which provided crude and adjusted values. Possible interactions between variables were also investigated.

Continuous variables were analyzed as such, including tests for linear trend, and later as categorical variables, using the likelihood ratio test (LRT). Missing values, when accounting for less than $10 \%$ of the observations, were recoded to the reference categories in the multivariate analyses.

\section{Analysis model}

The analysis model included the simultaneous introduction of all potential confounders: schooling, family income, skin color, marital status, age at menarche, number of abortions, age at first delivery, number of children, age at menopause, use of oral contraceptives, benign breast disease history, and family history of breast cancer. Subsequently, variables with $p<$ 0.2 were kept in the model as confounders so that the adjusted ratios could be obtained.

\section{Results}

Of the 250 incident cases of breast cancer, 168 $(62.7 \%)$ were from the city of Pelotas and 82 (32.8\%) were from neighboring cities. The mean age for both cases and controls was 47 years ( $\mathrm{SD}=6.5$ ). Age distribution of cases was as follows: $9.3 \% \leq 35$ years, $30.8 \%$ from 36 to 45 years, and $59.9 \% 45$ to 60 years. Age distribution of controls was: $10.5 \% \leq 35$ years, $32.9 \%$ from 36 to 45 years, and $56.5 \%$ from 45 to 60 years.
Quality control was performed by re-interviewing approximately $5 \%$ of cases and their respective controls. For every 15 cases encountered, one was randomly selected to be re-interviewed. Kappa statistic (Landis, 1977; Landis et al., 1977) was also calculated to check inter-observer agreement. The aim was to verify quality of interviews and selection. Kappa values for benign breast disease history were 0.82 for hospital-based and 0.9 for communitybased controls; for breastfeeding history, the corresponding kappa values were 0.76 and 0.82 , and 1.0 for cases.

Table 2 shows characteristics of cases and control groups. Among potential confounding variables, the adjusted odds ratio for breast cancer in women with higher schooling was 1.2 ( $95 \% \mathrm{Cl}: 0.6-2.3)$, with a linear trend $\mathrm{p}$-value of 0.28 , as compared to women with no schooling.

Women who gave birth after age 30 presented an $\mathrm{OR}=1.7(95 \% \mathrm{Cl}: 1.1-2.4)$, with a linear trend $p$-value of $<0.001$, as compared to women whose first delivery was before age 30 . In addition, for women with a history of benign breast disease, the odds ratio was 1.9 (95\% Cl: 1.0-3.2), with a linear trend $\mathrm{p}$-value of 0.028 . In women with more than four children there was a protective effect against breast cancer, with OR $=0.3(95 \% \mathrm{Cl}: 0.2-0.5)$, compared to nulliparous women. Women with a family history of breast cancer presented an OR of $2.6(95 \% \mathrm{Cl}: 1.8-3.2)$. Women with age at menopause over 50 showed an OR of 2.7 (95\% $\mathrm{Cl}:$ 1.6-4.6) as compared to pre-menopausal women.

The majority of the women had breastfed their children: $70.0 \%$ of cases and $80.5 \%$ of controls. The proportion of women who had breastfed six months or less was $28.4 \%$ for cases and $24.6 \%$ for controls. Some $19.8 \%$ of cases and $25.4 \%$ of controls had breastfed for at least two years (Table 3 ).

The odds ratio for women who had breastfed was 0.9 (95\% Cl: 0.8-1.2). For those who had breastfed for six months or less as compared to those who had never breastfed, OR was 1.0 (95\% Cl: 0.6-1.8). The OR for those who had breastfed for 24 months or more was 1.0 (95\% $\mathrm{Cl}$ : 0.6-1.9).

As shown in Table 4, the proportion of women who had breastfed was $74.5 \%$ among cases and $81.2 \%$ among controls in premenopausal women, and $70.0 \%$ among cases and $81.2 \%$ among controls in post-menopausal women. Pre- and post-menopause women presented odds ratios of 0.91 and 0.92 , respectively. Concerning duration of breastfeeding in preand post-menopausal women, the odds ratios 
Distribution of cases and controls and adjusted odds ratios for breast cancer according to selected variables.

Southern region of Rio Grande do Sul, Brazil, 1995-1998.

\begin{tabular}{|c|c|c|c|c|c|c|c|}
\hline \multirow{2}{*}{ Variable } & \multicolumn{2}{|c|}{ Hospital } & \multicolumn{2}{|c|}{ Community } & \multicolumn{3}{|c|}{ Odds ratios and $95 \% \mathrm{Cl}^{1}$} \\
\hline & Cases (\%) & Controls (\%) & Cases (\%) & Controls (\%) & Hospital & Community & Both \\
\hline \multicolumn{8}{|l|}{ Schooling } \\
\hline None & 14.5 & 22.7 & 14.3 & 10.3 & 1.0 & 1.0 & 1.0 \\
\hline 1 to 7 years & 50.0 & 56.2 & 53.6 & 65.3 & $1.3(0.7-2.3)$ & $0.8(0.4-1.5)$ & $0.9(0.5-1.8)$ \\
\hline$\geq 8$ years & 35.5 & 21.1 & 32.1 & 24.4 & $2.3(1.1-4.6)$ & $1.0(0.6-1.8)$ & $1.2(0.6-2.4)$ \\
\hline \multicolumn{8}{|l|}{ Skin color } \\
\hline Non-white & 14.5 & 18.6 & 16.1 & 12.5 & 1.0 & 1.0 & 1.0 \\
\hline White & 85.5 & 81.4 & 83.9 & 87.5 & $1.0(0.9-1.2)$ & $1.0(0.8-1.4)$ & $1.0(0.7-1.6)$ \\
\hline \multicolumn{8}{|l|}{ Marital status } \\
\hline Married & 75.6 & 84.1 & 77.4 & 88.1 & 1.0 & 1.0 & 1.0 \\
\hline Single & 24.4 & 15.9 & 22.6 & 11.9 & $1.2(0.7-1.9)$ & $1.3(1.0-1.7)$ & $0.9(0.7-1.3)$ \\
\hline \multicolumn{8}{|l|}{$\begin{array}{l}\text { Family history } \\
\text { of breast cancer }\end{array}$} \\
\hline No & 76.2 & 90.1 & 73.8 & 85.5 & 1.0 & 1.0 & 1.0 \\
\hline Yes & 23.8 & 9.9 & 26.2 & 14.5 & $3.1(1.9-5.1)$ & $2.0(1.3-3.3)$ & $2.6(1.8-3.7)$ \\
\hline \multicolumn{8}{|l|}{$\begin{array}{l}\text { Benign breast } \\
\text { disease history }\end{array}$} \\
\hline No & 89.5 & 94.6 & 90.5 & 95.6 & 1.0 & 1.0 & 1.0 \\
\hline Yes & 10.5 & 5.4 & 9.5 & 4.4 & $2.3(1.0-4.2)$ & $2.8(1.3-5.9)$ & $1.9(1.1-3.2)$ \\
\hline \multicolumn{8}{|l|}{ Age at menarche } \\
\hline$<12$ years & 41.3 & 40.7 & 47.0 & 44.8 & 1.0 & 1.0 & 1.0 \\
\hline$\geq 12$ years & 58.7 & 59.3 & 53.0 & 55.2 & $0.9(0.6-1.3)$ & $1.0(0.7-1.5)$ & $1.2(0.9-1.6)$ \\
\hline \multicolumn{8}{|l|}{ Age of first child } \\
\hline$\leq 30$ years & 70.3 & 86.0 & 74.4 & 79.0 & 1.0 & 1.0 & 1.0 \\
\hline$\geq 31$ years & 29.7 & 14.0 & 25.6 & 21.0 & $1.4(0.7-2.8)$ & $1.3(0.6-2.6)$ & $1.7(1.1-2.4)$ \\
\hline \multicolumn{8}{|c|}{ Number of children } \\
\hline None & 20.9 & 8.1 & 17.9 & 11.1 & 1.0 & 1.0 & 1.0 \\
\hline One & 16.9 & 13.6 & 16.1 & 14.9 & $0.5(0.2-0.9)$ & $0.8(0.4-1.6)$ & $0.5(0.3-0.9)$ \\
\hline Two & 20.9 & 24.2 & 22.6 & 26.2 & $0.3(0.1-0.6)$ & $0.6(0.3-1.4)$ & $0.4(0.2-0.6)$ \\
\hline Three & 20.3 & 18.0 & 21.4 & 19.4 & $0.4(0.2-0.8)$ & $0.8(0.4-1.9)$ & $0.5(0.3-0.8)$ \\
\hline Four or more & 20.9 & 36.0 & 22.0 & 28.4 & $0.3(0.2-0.6)$ & $0.5(0.2-1.0)$ & $0.3(0.2-0.5)$ \\
\hline \multicolumn{8}{|c|}{ Number of abortions } \\
\hline None & 62.8 & 59.3 & 62.5 & 66.2 & 1.0 & 1.0 & 1.0 \\
\hline One & 19.8 & 23.4 & 17.9 & 19.0 & $0.8(0.5-1.3)$ & $1.1(0.6-1.8)$ & $0.9(0.6-1.3)$ \\
\hline Two or more & 17.4 & 17.2 & 19.6 & 14.7 & $0.9(0.6-1.5)$ & $1.4(0.8-2.4)$ & $1.1(0.7-1.7)$ \\
\hline \multicolumn{8}{|l|}{$\begin{array}{l}\text { Use of oral } \\
\text { contraceptives }\end{array}$} \\
\hline No & 26.2 & 27.3 & 25.0 & 22.2 & 1.0 & 1.0 & 1.0 \\
\hline Yes & 73.8 & 72.7 & 75.0 & 78.8 & $1.1(0.7-1.6)$ & $0.9(0.6-1.6)$ & $0.9(0.9-1.2)$ \\
\hline \multicolumn{8}{|l|}{ Age at menopause } \\
\hline Pre-menopause & 48.3 & 48.8 & 40.5 & 55.8 & 1.0 & 1.0 & 1.0 \\
\hline$<50$ years & 15.7 & 23.4 & 39.3 & 29.6 & $0.7(0.4-1.3)$ & $2.8(1.6-5.0)$ & $1.6(1.0-2.3)$ \\
\hline$\geq 50$ years & 36.0 & 27.7 & 20.2 & 14.7 & $1.4(0.8-2.5)$ & $4.3(2.2 .-8.0)$ & $2.7(1.6-4.6)$ \\
\hline Total & 172 & 516 & 168 & 504 & & & $250 \quad 1.020$ \\
\hline
\end{tabular}

1 Adjusted odds ratio among all variables simultaneously.

$p=p$-value; $p^{*}=p$-value for linear trend; $95 \% \mathrm{Cl}=95 \%$ confidence interval 
were $1.17(95 \% \mathrm{Cl}: 0.6-3.4)$ and $0.91(95 \% \mathrm{Cl}$ : 0.3-1.6), respectively, for those who breastfed for six months. For those who breastfed for over 24 months the odds ratios were $0.95(95 \% \mathrm{Cl}$ : $0.5-3.5)$ and $1.27(95 \% \mathrm{Cl}: 0.5-3.1)$, in pre-and post-menopause.

\section{Discussion}

This study's methodological characteristics merit a specific discussion. Two groups of controls (hospital and community) were included and evaluated jointly, providing a total of 1,020 controls. This design had the advantage of reducing potential selection bias, a major issue in case-control studies. The similarity of results between the two types of controls allowed the joint analysis to be maintained, thereby increasing statistical power.

Among the study's potential limitations, in relation to recall it should be noted that information on breastfeeding often refers to a fairly distant period of time prior to the appearance of breast cancer. As compared to controls, women with breast cancer also tend to remember more facts that may be related to the disease.

Among positive aspects, the degree of agreement between the data obtained by interviewers and supervisors is relevant. The high kappa values also indicate adequate quality control in the data collection.
In order to avoid bias, interviews of cases and respective controls were performed by the same interviewer. In addition, the proportion of women who had breastfed in the two control groups was similar, thus attesting to the adequacy of the selection procedure: $79.7 \%$ in hospital controls and $80.4 \%$ in community controls.

According to the results there was no association between breastfeeding and breast cancer. These results are similar to those from several other studies, with both case-control and cohort designs. However, Hardy et al. (1993) and OlayaContreras et al. (1999) indicated a high protective effect against breast cancer for women who breastfed, including a dose-response trend. The former study, conducted in Brazil, demonstrated marked protection against breast cancer in the multivariate analysis.

In the present study, no overall protective effect of breastfeeding was found among women in pre-menopause. Our findings were similar to those of other studies in relation to the occurrence and duration of breastfeeding and menopause status (Brintom et al., 1995; London et al., 1990; Michels et al., 1996, 2001; Thomas \& Noonan, 1993). However, some casecontrol studies demonstrated a protective effect in pre-menopausal women (Byers et al., 1985; McTiernan \& Thomas, 1986; Newcomb et al., 1994; Tryggvadottir et al., 2001; UK National Case-Control Study Group, 1993), stating that

Table 3

Odds ratio and $95 \%$ confidence interval for breast cancer cases and hospital and community controls according to occurrence and duration of breastfeeding.

\begin{tabular}{|c|c|c|c|c|c|c|c|}
\hline \multirow[t]{2}{*}{ Variable } & \multicolumn{2}{|c|}{ Hospital } & \multicolumn{2}{|c|}{ Community } & \multicolumn{3}{|c|}{ Odds ratios and $95 \% \mathrm{Cl}$} \\
\hline & Cases (\%) & Controls (\%) & Cases $(\%)$ & Controls (\%) & Hospital & Community & Both \\
\hline \multicolumn{8}{|l|}{ Ever breastfed } \\
\hline No & 32.6 & 20.3 & 28.6 & 18.7 & 1.0 & 1.0 & 1.0 \\
\hline Yes & 67.4 & 79.7 & 71.4 & 81.3 & $0.9(0.8-1.3)$ & $1.1(0.8-1.6)$ & $0.9(0.8-1.2)$ \\
\hline \multicolumn{8}{|c|}{ Duration breastfeeding } \\
\hline Never & 39.0 & 30.0 & 27.4 & 18.5 & 1.0 & 1.0 & 1.0 \\
\hline$\leq 6$ months & 17.4 & 16.7 & 26.2 & 29.2 & $0.8(0.6-1.3)$ & $0.9(0.6-1.2)$ & $1.0(0.6-1.8)$ \\
\hline 7-12 months & 14.0 & 17.1 & 13.1 & 15.7 & $0.9(0.6-1.3)$ & $0.9(0.7-1.2)$ & $0.9(0.4-1.8)$ \\
\hline 13-24 months & 11.0 & 12.8 & 12.6 & 14.7 & $0.9(0.5-1.2)$ & $0.8(0.6-1.1)$ & $0.8(0.4-1.6)$ \\
\hline$\geq 25$ months & 18.0 & 13.8 & 20.8 & 22.0 & $0.0(0.6-1.2)$ & $0.9(0.7-1.2)$ & $1.0(0.6-1.9)$ \\
\hline Total & 172 & 516 & 168 & 504 & & & $250 \quad 1.020$ \\
\hline
\end{tabular}

Note: Adjusted for schooling, skin color, marital status, family history of breast cancer, benign breast disease, age at menarche, age of first child, parity, abortions, use of oral contraceptives, and age at menopause. $p=p$-value; $p^{*}=p$-value for linear trend; $95 \% \mathrm{Cl}=95 \%$ confidence interval 
Distribution of cases and controls in pre- and post-menopausal women, according to the occurrence of breastfeeding.

\begin{tabular}{|c|c|c|c|c|c|c|c|c|c|c|c|c|}
\hline \multirow[b]{3}{*}{ Variable } & \multicolumn{5}{|c|}{ Pre-menopause } & \multicolumn{6}{|c|}{ Post-menopause } & \multirow[b]{3}{*}{$95 \% \mathrm{Cl}$} \\
\hline & \multicolumn{2}{|c|}{$\begin{array}{c}\text { Cases } \\
\mathrm{n}=110\end{array}$} & & \multicolumn{2}{|c|}{$\begin{array}{l}\text { Control } \\
n=533\end{array}$} & \multirow[b]{2}{*}{$95 \% \mathrm{Cl}$} & \multicolumn{2}{|c|}{$\begin{array}{l}\text { Cases } \\
\mathrm{n}=140\end{array}$} & \multicolumn{3}{|c|}{$\begin{array}{l}\text { Controls } \\
n=487\end{array}$} & \\
\hline & $\mathrm{n}$ & $\%$ & $\mathrm{n}$ & $\%$ & $A O R$ & & $\mathrm{n}$ & $\%$ & $n$ & $\%$ & $A O R$ & \\
\hline Ever breastfed & & & $p=0.8$ & & & & & & 0.19 & & & \\
\hline No & 28 & 25.5 & 100 & 18.8 & 1.00 & - & 42 & 30.0 & 100 & 20.3 & 1.00 & - \\
\hline Yes & 82 & 74.5 & 433 & 81.2 & 0.91 & $0.4-2.2$ & 98 & 70.0 & 387 & 79.7 & 0.92 & $0.4-1.5$ \\
\hline $\begin{array}{l}\text { Duration } \\
\text { of breastfeeding }\end{array}$ & & & $*=0.9$ & & & & & & $=0.63$ & & & \\
\hline Never & 28 & 25.5 & 100 & 18.8 & 1.00 & - & 42 & 30.0 & 100 & 20.3 & 1.00 & - \\
\hline$\geq 6$ months & 36 & 32.7 & 169 & 31.7 & 1.17 & $0.6-3.4$ & 36 & 25.7 & 131 & 26.7 & 0.91 & $0.3-1.6$ \\
\hline 7-12 months & 14 & 12.7 & 85 & 15.9 & 1.11 & $0.4-3.2$ & 17 & 12.1 & 66 & 13.5 & 1.00 & $0.5-3.0$ \\
\hline 13-24 months & 13 & 11.8 & 75 & 14.1 & 1.12 & $0.5-4.0$ & 16 & 11.4 & 65 & 13.5 & 1.00 & $0.4-2.8$ \\
\hline$\leq 25$ months & 21 & 19.1 & 104 & 19.5 & 0.95 & $0.5-3.5$ & 29 & 20.7 & 125 & 25.9 & 1.27 & $0.5-3.1$ \\
\hline
\end{tabular}

$A O R=$ Adjusted for schooling, skin color, marital status, family history of breast cancer, benign breast disease, age of menarche, age of first son, parity, abortions, use of oral contraceptives and age of menopause. $p=p$-value; $p^{*}=p$-value for linear trend $; 95 \% \mathrm{Cl}=95 \%$ confidence interval

this effect was more pronounced in women who breastfed at an early age.

In several epidemiological investigations, and particularly in a recent meta-analysis of 53 studies (Collaborative Group on Hormonal Factors in Breast Cancer, 2002), breastfeeding has been identified as a protective factor against breast cancer. The association between lactation and the reduction in breast cancer incidence has been limited and inconsistent. Changes in breastfeeding behavior worldwide affect not only infant feeding patterns (natural vs. artificial milk), but breastfeeding duration and intensity as well. This diversity could explain the different results obtained by different studies.

The effect of Iactation appears to be small (if any) and limited to a minority of women at risk of breast cancer. It is not clear why breastfeeding would reduce breast cancer risk. A biological basis for an inverse association between breastfeeding and breast cancer risk has not been adequately elucidated, although several mechanisms have been postulated. One hypothesis is that lactation causes long-term endogenous hormonal changes, possibly reduced estrogen, and increased prolactin production, which may decrease a woman's cumulative exposure to estrogen, thereby inhibiting the initiation or growth of breast cancer cells (Freudenheim et al., 1997). It has also been suggested that a protective effect of breastfeeding on breast cancer risk may be attributed to the ex- cretion of carcinogenic agents from breast ductal tissue through breastfeeding (Titus-Ernstoff et al., 1998). According to another biologically plausible hypothesis, women with only one child and who gave birth before the age of 30 could be at lesser risk of breast cancer (Gruenke et al., 1987).

The importance of age at first gestation for the modulation of breast cancer risk is derived from experiments on animals particularly susceptible to carcinogenesis (Brinton et al., 1983). However, in a rat model, Russo et al. (1982) observed no protection against breast cancer from either breastfeeding or pregnancy.

Lactation, as a potentially modifiable behavior, could theoretically contribute to a decrease in the incidence of breast cancer. However, the results of the present study, together with the majority of the literature on this subject, fail to support a causal relationship. Further studies on the subject are necessary, especially among pre-menopausal and low-parity women. It would also be useful to assess the effect of breastfeeding intensity by comparing exclusive and partial breastfeeding. On the other hand, the effects of breastfeeding on child health are well established and its promotion remains a valid public health goal (Cunningham et al., 1991). 


\section{References}

BARROS, F. C.; VICTORA, C. G. \& VAUGHAN, J. P., 1986. Breastfeeding and socioeconomic status in Southern Brazil. Acta Paediatrica Scandinavica, 75:558-562.

COLLABORATIVE GROUP ON HORM ONAL FACTORS IN BREAST CANCER, 2002. Breast cancer and Breastfeeding: Collaborative reanalysis of individual data from 47 epidemiological studies in 30 countries, including 50,302 women with breast cancer and 96973 women without the disease. Lancet; 360:187-196.

BORING, C. C.; SQUIRES, T. S.; TONG, T. \& MONTGOMERY, S., 1994. Cancer statistics, 1994. CA: A Cancer J ournal for Clinicians, 44:7-26.

BRESLOW, N. \& DAY, N., 1980. Statistical Methods in Cancer Research: The Analysis of Case-Control Studies. Scientific Publications 32. Lyon: International Agency for Research on Cancer.

BRINTON, L. A.; HOOVER, R. \& FRAU MENI J r., J. F., 1983. Reproductive factors in the etiology of breast cancer. British Journal of Cancer, 47:757762.

BRINTON, L. A.; POTISCHMAN, N. A.; SWANSON, C. A.; SCHOENBERG, J. B.; COATES, R. J.; GAMMON, M. D.; MALONE, K. E.; STANFORD, J. L. \& DALING, J. R., 1995. Breastfeeding and breast cancer risk. Cancer Causes Control, 6:199-208.

BYERS, T.; GRAHAM, S.; RZEPKA, T. \& MARSHALL, J., 1985. Lactation and breast cancer. Evidence for a negative association in premenopausal women. American Journal of Epidemiology, 121:664-674.

CHAGAS, R., 1994. Aspectos populacionais do câncer de mama. Revista Brasileira de Mastologia, 3:11-16.

CUNNINGHAM, A. S.; JELLIFFE, D. B. \& JELLIFFE, E. F., 1991. Breast-feeding and health in the 1980s: A global epidemiologic review. Journal of Pediatrics, 118:659-666.

FENTIMAN, I., 1993. Causas de Câncer de Mama: Diagnóstico e Tratamento do Câncer Inicial da Mama. São Paulo: Artes Médicas.

FREUDENHEIM , J. L.; MARSHALL, J. R.; GRAHAM, S.; LAUGHLIN, R.; VENA, J. E.; BANDERA, E.; MUTI, P.; SWANSON, M. \& NEM OTO, T., 1994. Exposure to breastmilk in infancy and the risk of breast cancer. Epidemiology, 5:324-331.

FREUDENHEIM, J. L.; MARSHALL, J. R.; VENA, J. E.; MOYSICH, K. B.; MUTI, P.; LAUGHLIN, R.; NEMOTO, T. \& GRAHAM , S., 1997. Lactation history and breast cancer risk. American Journal of Epidemiology, 146:932-938.

GRUENKE, L. D.; WRENSCH, M. R.; PETRAKIS, N. L.; MIIKE, R.; ERNSTER, V. L. \& CRAIG, J. C., 1987. Breast fluid cholesterol and cholesterol epoxides: Relationship to breast cancer risk factors and other characteristics. Cancer Research, 47:54835487.

HARDY, E.; PINOTTI, J.; OSIS, J. \& FAÚNDES, A., 1993. Reproductive variables and risk of breast cancer: A case-control study carried out in Brazil. Boletín de la Oficina Sanitaria Panamericana, 115:93102.

HARRIS, J. R.; LIPPMAN, M. E.; VERONESI, U. \& WILLETT, W., 1992. Breast cancer (1). New England Journal of Medicine, 327:319-328.
HORTA, B.; OLINTO, M.; VICTORA, C.; BARROS, F. \& GUIM ARÃES, P., 1996. Amamentação e padrões alimentares em crianças de duas cortes de base populacional no Sul do Brasil: Tendências e diferenciais. Cadernos de Saúde Pública, 12:43-48.

HULKA, B. S. \& STARK, A. T., 1995. Breast cancer: Cause and prevention. Lancet, 346:883-887.

KELSEY, L. J.; MARILIE, D. D.; ESTHER, M. J., 1993. Reproductive and hormonal risk factors. Epidemiologic Reviews, 15:36-47.

LA VECCHIA, C.; NEGRI, E.; DECARLI, A.; FASOLI, M. $\&$ CISLAGHI, C., 1990. Cancer mortality in Italy: An overview of age-specific and age-standardized trends from 1955 to 1984. Tumori, 76:87-166.

LANDIS, J. R. \& KOCH, G. G., 1977. The measurement of observer agreement for categorical data. Biometrics, 33:159-174.

LIMA, M. G.; KOIFMAN, S.; SCAPULATEMPO, I.; PEIXOTO, M.; NAOMI, S. \& AM ARAL, M., 2001. Risk Factors for Breast Cancer among rural Terêna Indian women in the State of Mato Grosso do Sul, Brazil. Cadernos de Saúde Pública, 17:1537-1544.

LIPWORTH, L.; BAILEY, L. R. \& TRICHOPOULOS, D., 2000. History of breastfeeding in relation to breast cancer risk: A review of the epidemiologic literature. Journal of the National Cancer Institute, 92:302-312.

LONDON, S. J.; COLDITZ, G. A.; STAMPFER, M. J.; WILLETT, W. C.; ROSNER, B. A.; CORSANO, K. \& SPEIZER, F. E., 1990. Lactation and risk of breast cancer in a cohort of US women. American Journal of Epidemiology, 132:17-26.

MARCUS, P. M.; BAIRD, D. D.; MILLIKAN, R. C.; MOORMAN, P. G.; QAQISH, B. \& NEWMAN, B., 1999. Adolescent reproductive events and subsequent breast cancer risk. American Journal of Public Health, 89:1244-1247.

MCTIERNAN, A. \& THOMAS, D. B., 1986. Evidence for a protective effect of lactation on risk of breast cancer in young women. Results from a case-control study. American Journal of Epidemiology, 124:353-358.

MICHELS, K. B.; WILLETT, W. C.; ROSNER, B. A.; MANSON, J. E.; HUNTER, D. J.; COLDITZ, G. A.; HANKINSON, S. E. \& SPEIZER, F. E., 1996. Prospective assessment of breastfeeding and breast cancer incidence among 89,887 women. Lancet, 347: 431-436.

MICHELS K.; TRICHOPOULOS D.; ROSNER B.; HUNTER D.; COLDITZ G.; HANKINSON S.; SPEIZER, F. E. \& WILLETT, W. C., 2001. Being breastfed in infancy and breast cancer incidence in adult life: Results from the two nurses' health studies. American Journal of Epidemiology, 153:275-283.

MILLER, A. B. \& BULBROOK, R. D., 1986. UICC Multidisciplinary Project on Breast Cancer: The epidemiology, etiology and prevention of breast cancer. International J ournal of Cancer, 37:173-137.

NEWCOMB, P. A.; STORER, B. E.; LONGNECKER, M. P.; MITTENDORF, R.; GREENBERG, E. R.; CLAPP, R. W.; BURKE, K. P.; WILLETT, W. C. \& MACMAHON, B., 1994. Lactation and a reduced risk of premenopausal breast cancer. New England Journal of Medicine, 330:81-87. 
OLAYA-CONTRERAS, P.; BUEKENS, P.; LAZCANOPONCE, E.; VILLAMIL-RODRIGUEZ, J. \& POSSOVALENCIA, H. J., 1999. Factores de riesgo reproductivo asociados al cáncer mamario, en mujeres colombianas. Revista de Saúde Pública, 33:237245.

REBELO, M. A. S., 1994 . Estimate of the incidence \& mortality by breast cancer in Brazil. Revista Brasileira de Mastologia, 4:11-14.

RUSSO, J. \& RUSSO, I. H., 1995. The etiopathogenesis of breast cancer prevention. Cancer Letters, 90: 81-89.

RUSSO, J.; TAY, L. K. \& RUSSO, I. H., 1982. Differentiation of the mammary gland and susceptibility to carcinogenesis. Breast Cancer Research and Treatment, 2:5-73.

SCHLESSELM AN, J. J., 1982. Case-Control Studies Design, Conduct, Analysis. New York: Oxford University Press.

THOMAS, D. B. \& NOONAN, E. A., 1993. Breast cancer and prolonged lactation. The WHO Collaborative Study of Neoplasia and Steroid Contraceptives. International Journal of Epidemiology, 22:619-626
TRYGGVADOTTIR, L.; TULINIUS, H.; EYFJORD, J. E. \& SIGURVINSSON, T., 2001 Breastfeeding and reduced risk of breast cancer in an Icelandic cohort study. American Journal of Epidemiology, 154:3742.

TITUS-ERNSTOFF, L.; EGAN, K. M.; NEWCOMB, P. A.; BARON, J. A.; STAM PFER, M.; GREENBERG, E. R.; COLE, B. F.; DING, J.; WILLETT, W. \& TRICHOPOULOS, D., 1998. Exposure to breast milk in infancy and adult breast cancer risk. Journal of the National Cancer Institute, 90:921-924.

UNITED KINGDOM NATIONAL CASE-CONTROL STUDY GROUP, 1993. Breastfeeding and risk of breast cancer in young women. BMJ, 307:17-20.

Recebido em 23 de julho de 2002

Versão final reapresentada em 31 de janeiro de 2003

Aprovado em 6 de junho de 2003 